\title{
Del amigo del país al ciudadano útil: una aproximación al discurso patriótico en la Real Sociedad Económica Matritense de Amigos del País en el Antiguo Régimen
}

\author{
Elisa Martín-Valdepeñas YagüE ${ }^{1}$ \\ Sociedad Española de Estudios del Siglo XVIII \\ mmartinva1@alumno.uned.es
}

Fecha de recepción: 23/03/2012

Fecha de aceptación: 15/09/2012

\section{RESUMEN}

La Real Sociedad Económica de Amigos del País de Madrid, fundada en 1775, fue una destacada corporación propagandista de los logros de la Ilustración, e intentó y procuró estimular, a través de los escritos de sus socios, que las minorías abiertas a las reformas unieran sus esfuerzos para alcanzar la felicidad pública, tarea en la que los socios consideraban debía participar toda la colectividad, empezando por el rey, al que exaltaron por su decidido interés en el progreso económico y social de España. En su prolija obra impresa se aprecia la recurrencia continua al uso de palabras tales como patria, nación, patriota e, incluso, ciudadano. Vocablos utilizados, en parte, con significado impreciso. En estos textos, estos hombres se definieron a sí mismos como patriotas, ya que estaban persuadidos de que trabajaban por el bien común.

Palabras clave: Real Sociedad Económica Matritense de Amigos del País, Ilustración, Carlos III, Carlos IV, Patriotismo.

\section{From Friend of the Country to Helpful Citizen: an Approach to Patriotic Speech at the Royal Economic Society of Madrid under the Old Regime}

\begin{abstract}
The Royal Economic Society of Madrid, founded in 1775, was a leading propagandist for the achievements of the Enlightenment and attempted through its writings to encourage minorities open to reform to work together to promote public happiness. The society believed the entire community should be involved in this task, beginning with the King, whom they extolled for his interest in the economic and material progress of Spain. In their prolific writings, they repeatedly used words such as homeland, nation, patriotic, and even citizen, often with deliberate vagueness. These men portrayed themselves as patriots through their writings, since they felt they were working for the common good.
\end{abstract}

Key words: Royal Economic Society of Madrid, Enlightenment, King Charles III of Spain, King Charles IV of Spain, Patriotism.

1 Agradezco los comentarios y sugerencias a este texto de Irene Castells Oliván, Marta Ruiz Jiménez y Juan José Gómiz León. 
«Entre otros muchos establecimientos que enlazan el glorioso Reinado de V. M. será ciertamente grata a los venideros la erección de esta Sociedad, y de otras que a su ejemplo se propagan incesantemente en el Reino.

Los siglos futuros tendrán la satisfacción de corregir y adicionar nuestras observaciones. Al presente tiempo se le hará la justicia de haber acertado en unir a beneficio común los patriotas honrados en la Corte y en las provincias» ${ }^{2}$

\section{Introducción}

Durante la Guerra de la Independencia, y especialmente en el Cádiz de las Cortes, vocablos como nación, patria y pueblo, entre otros, se repitieron constantemente en la prensa y la literatura de circunstancia publicada durante la contienda ${ }^{3}$. Los partidarios de Fernando VII dieron un impulso decisivo al significado de la palabra patriotismo, voz ya utilizada en el siglo XVIII en el sentido de «predisposición para sacrificarse por la colectividad» ${ }^{4}$. Sin embargo, la coyuntura de los seis años de guerra dotó a esta palabra de un valor simbólico, emocional e, incluso político del que hasta entonces probablemente carecía ${ }^{5}$.

La identidad española, que, a sus definidos rasgos étnicos-culturales, unía la dimensión religiosa y política, es decir, la fe católica compartida y la lealtad al soberano, se había forjado a lo largo de los siglos en torno a un imaginario colectivo de origen medieval que subordinaba política a religión ${ }^{6}$. Fue en el período histórico de la Ilustración cuando la monarquía procedió decididamente a reforzar su autoridad como institución situada por encima de la sociedad, mediante la identificación y la adhesión de sus súbditos a una entidad más o menos cohesionada, el Estado. Así pues, la monarquía y la sociedad se mantenían unidas por determinados vínculos

2 «Dedicatoria», Memorias de la Sociedad Económica de Madrid, t. I (en adelante, Memorias, t. I), Madrid, Imp. de don Antonio de Sancha, 1780, pp. IV-V.

3 Un análisis desde el punto de vista jurídico-positivo del concepto de nación en las Cortes de Cádiz puede verse en Varela Suanzes-Carpegna, Joaquín: La Teoría del Estado en las Cortes de Cádiz, Madrid, CEPC, 2011, pp. 137-217. Sobre la bibliografía en torno a la nación en el siglo XVIII y principios del XIX, véase Calvo Maturana, Antonio y Amador González Fuertes, Manuel: «Monarquía, nación y guerra de la Independencia: debe y haber historiográfico en torno a 1808», Cuadernos de Historia Moderna, Anejos, VII (2008), pp. 321-377 y, específicamente, sobre la Constitución de 1812 y el concepto de nación definido por este texto, véase Clavero SALVAdor, Bartolomé: «Cádiz en España: Signo constitucional, Balance historiográfico, Saldo ciudadano», en Ramos Santana, Alberto (coord.): Lecturas sobre 1812, Cádiz, Ayuntamiento y Universidad de Cádiz, 2007, pp. 21-72. Véase también Morales Moya, Antonio y Romero Ferrer, Alberto (coords.): «La nación liberal», Cuadernos Dieciochistas, 12 (2011), pp. 13-141, y especialmente el artículo del primero, «La Nación española preconstitucional», pp. 19-36.

4 Álvarez Junco, José: Mater Dolorosa. La idea de España en el siglo XIX, Madrid, Taurus, 2001, p. 33.

5 Detrás de la lucha por la independencia y el protagonismo de la nación política está «la elaboración de un pensamiento político y económico preliberal en los últimos años del reinado de Carlos III». EloRzA Domínguez, Antonio: «Contra dos tiranías: el liberalismo español de 1808», en Ramos Santana, op. cit. (nota 3), p. 150 .

6 Fernández Sebastián, Javier: «España, monarquía y nación. Cuatro concepciones de la comunidad política española entre el Antiguo Régimen y la Revolución liberal», Studia Historica-Historia Contemporánea, 12 (1994), p. 45. 
culturales y simbólicos ${ }^{7}$. A las justificaciones tradicionales de la soberanía real (legitimidad hereditaria, la voluntad divina y el derecho de conquista), los Borbones, en su aspiración de consolidar una monarquía nacional y homogénea, añadieron un nuevo fundamento a la naturaleza de su autoridad, el de su utilidad a la sociedad, es decir, «ser el instrumento impulsor de medidas que elevarían los niveles de seguridad y bienestar de sus súbditos» ${ }^{8}$. En este nuevo discurso legitimador, en el que el rey se convertía en director de las iniciativas renovadoras, los súbditos también desempeñaban un nuevo papel, el de colaboradores activos del Estado ${ }^{9}$. El bien común era la aspiración legítima de la comunidad a la que el individuo debía subordinar sus intereses particulares en aras a contribuir de forma desinteresada a esa ambición colectiva que era el logro de la felicidad pública.

Las élites ilustradas se adhirieron con entusiasmo al proceso renovador de homogeneización cultural impulsado por los Borbones españoles, pues vieron en las reformas la oportunidad de recuperar el prestigio de la colectividad, y al mismo tiempo alcanzar muchas de sus reivindicaciones ${ }^{10}$. Parte de estas energías regeneracionistas fueron canalizadas por las Sociedades Económicas de Amigos del País que, en algunos casos, también fueron conocidas como «patrióticas», una de las novedades más representativas de la época ${ }^{11}$. Instituciones que, a la vez que se empeñaron en desarrollar sus programáticas ideas económicas favorables al crecimiento y del progreso,

7 Según Javier Fernández Sebastián: «Desde los presupuestos clásicamente reformistas la nación es concebida como un cuerpo social más o menos pasivo y homogéneo bajo la autoridad del monarca ilustrado, que debe procurar por todos los medios su bienestar, así como la cohesión entre los elementos integrantes del Estado. La Corona estaría en consecuencia legitimada para adoptar un papel mucho más activo, llegando incluso a intervenir y a tomar decisiones de gobierno en asuntos que eventualmente pudieran colisionar con derechos adquiridos e intereses privados». Fernández Sebastián, Ibidem, pp. 53-54.

8 Álvarez Junco, op. cit. (nota 4), p. 103. Una interesante reflexión sobre el reformismo ilustrado de los monarcas españoles y su modernidad, puede verse en Albareda SALVADó, Joaquím: «El debate sobre la modernidad del reformismo borbónico», Revista HMiC, X (2012), pp. 6-18. <http://webs2002.uab.es/hmic>.

9 Véase el capítulo «Preludio al nacionalismo: oposiciones religiosas y nacionales a principios de la Europa moderna» en el que se analiza el surgimiento de conciencias pre-nacionales en la Europa de los siglos XVII y XVIII, que adquirieron su legitimación y justificación al entrar en conflicto con el Estado. BreUILLY, John: Nacionalismo y Estado, Barcelona, Pomares-Corredor, 1990.

10 Elorza Domínguez, Antonio: La ideología liberal en la Ilustración española, Madrid, Tecnos, 1970, pp. 36-41. En otro texto posterior, Antonio Elorza aclara que «El sentimiento nacional de la elite ilustrada surge en gran medida del reconocimiento de la extrema dificultad con que tropieza el reformismo, dado el vigor de las fuerzas dispuestas a mantener intactos los privilegios, y sobre todo el poder de la Iglesia y de la Inquisición, apoyados en la monarquía». Sin embargo, para Pérez Garzón, «ni el intento de organizar la riqueza de la monarquía -propuesta que ya se podría calificar de protonacional- con el catastro del marqués de la Ensenada, ni las Sociedades Económicas de Amigos del País, ni las guerras exteriores fueron catalizadores para la cristalización de un sentimiento nacional, aunque exhumemos a ilustrados y textos en esa dirección». Elorza Domínguez, op. cit. (nota 5), p. 145 y Pérez Garzón, Juan Sisinio: «El nacionalismo español en sus orígenes: factores de configuración», Ayer, 35 (1999), p. 66.

11 Llombart Rosa, Vicente y Astigarraga Goenaga, Jesús: «Las primeras "antorchas de la economía”: las sociedades económicas de amigos del país en el siglo XVIII», en Fuentes Quintana, Enrique (dir.): Economía y Economistas españoles, t. III, La Ilustración, Barcelona, Galaxia Gutenberg y Círculo de Lectores, 2000, p. 677. Sobre las diferencias entre las Sociedades Económicas de Amigos del País y las Sociedades Patrióticas en el Trienio Liberal y el origen de estas últimas, véase Gil Novales, Alberto: Las Sociedades Patrióticas (1820-1823), Las libertades de expresión y de reunión en el origen de los partidos políticos, Madrid, Tecnos, 1975, t. I, pp. 6-16 y del mismo, «Las Sociedades Económicas y las Sociedades Patrióticas en 1820», Moneda y Crédito, 116 (1971), pp. 33-64. 
también desarrollaron una labor propagandística evidente de exaltación de la monarquía dieciochesca española, tarea en la que se mostraron muy activas a través de los discursos de ingreso, oraciones gratulatorias, elogios fúnebres, etc. En cierto modo, ellas eran la realización en miniatura, a título ejemplar o experimental, de la nación ideal de la Ilustración ${ }^{12}$. Su carácter interclasista, aunque elitista, suponía un modelo de colaboración social para el logro del bien común que conectaba a la perfección con los postulados que la Corona trataba de acometer.

\section{Campomanes: el ideólogo de las sociedades económicas}

En su Discurso sobre el fomento de la industria popular, publicado en 1774, Pedro Rodríguez de Campomanes, una de las personalidades más destacadas del reinado de Carlos III, alentó a las minorías sensibles a las novedades esparcidas por el territorio peninsular a que unieran sus esfuerzos, encauzándolos a través de la creación de las Sociedades Económicas de Amigos del País ${ }^{13}$. A lo largo de las páginas de su Discurso, proclamaba su confianza en el papel que podían desarrollar, puesto que la monarquía se mostraba incapaz de dirigir eficazmente, ella sola, sin colaboración, el desarrollo ${ }^{14}$. Por eso su programa de progreso implicaba a todos los habitantes, no sólo a los poderes públicos, pues «Es forzoso que la nación se instruya de su situación y se ponga en movimiento activo para promover las ganancias y libertarse de las pérdidas que sufra en la balanza con sus vecinos. Un Estado es, en sustancia, una gran familia cuyos individuos deben concurrir unidamente al bienestar de la causa común» ${ }^{15}$.

El prócer asturiano consideraba que, con la ayuda desinteresada y entusiasta de los «Amigos del País», se podían encauzar eficazmente los ingentes esfuerzos necesarios para conseguir una modernización en la que debía implicarse toda la colectividad. Por eso añadía: «Puede conjeturarse que, acertándose con el método de inflamar en el amor del bien público a estas Sociedades, logrará España reunir en su seno los conocimientos que han costado siglos y tesoros inmensos a otras naciones adquirirlos e irlos rectificando con gran fatiga hasta llegar a su debida perfección» ${ }^{16}$.

El Discurso sobre el fomento de la industria popular supuso la señal de partida para la fundación de sociedades económicas por todos los territorios de la monarquía. Entre ellas, la de Madrid, que inmediatamente fue autorizada por el gobierno. Así, pocos meses más tarde, con motivo del discurso que pronunció en la inauguración de la Real Sociedad Económica Matritense de Amigos del País, Campomanes con-

12 VAREla TorTajada, Javier: «Nación, patria y patriotismo en los orígenes del nacionalismo español», Studia Historica-Historia Contemporánea, 12 (1994), p. 34.

13 Anes Álvarez de Castrillón, Gonzalo: Economía e Ilustración en la España del siglo XVIII, Barcelona, Ariel, 1972, pp. 25-26.

14 «No es accesible a ningún Gobierno velar en cosas tan extendidas que abrazan todo el Reino. Y esta reflexión obliga a pensar en Sociedades Económicas, que sobre estas máximas vean lo que conviene a cada Provincia, cuáles impedimentos lo retardan y los medios seguros de removerlos y establecer los modos sólidos que han de regir este género de industrias». RodRíguez de CAMPOMANES, Pedro: «Discurso sobre el fomento de la industria popular», El fomento de la industria popular y la educación popular de los artesanos, Oviedo, Grupo Editorial Asturiano, 1991, p. 66.

15 Ibidem, p. 97.

16 Ibid., p. 92. 
tinuaba su tarea de implicar a los reformistas, animando a su auditorio a trabajar por la regeneración:

Llenos de celo por la patria los Amigos del País, y sin miras personales, han erigido esta Sociedad en Madrid para contribuir con sus auxilios y con sus luces a desterrar la ociosidad criminosa, y a propagar la industria, las artes y la agricultura, preservando las familias desvalidas de caer en este miserable estado. En la empresa de la Sociedad está cifrado nuestro instituto: Socorre enseñando. Aconseja, favorece y presenta los modos de instruir con utilidad general, aun a los aplicados ${ }^{17}$.

Pero el entonces Fiscal del Consejo de Castilla no se limitaba a alentar a sus oyentes, sino que ya concretaba las condiciones que debían observar todos aquellos que se habían acercado de forma desinteresada a la recién nacida Sociedad:

Es preciso que aquellos hombres patrióticos a quienes sobre algún tiempo, están dotados de luces, caridad, y buen celo tomen sobre sí tamaña diligencia, reuniéndose como vosotros lo acabáis de hacer en una Sociedad vigilante, e instruida, comunicándose de buena fe sus nociones para hacer participantes de ellas a cuantos las necesiten, reduciéndoles en lo posible a práctica y aun a general enseñanza ${ }^{18}$.

Definidos por él como «patriotas honrados», cuyas actividades eran amparadas y protegidas por el rey, su camino hacia el éxito estaba garantizado con poco que los esfuerzos fructificaran ${ }^{19}$. Esta doble característica de amor a la patria y lealtad a la monarquía, fue lo que definió a estos hombres: «Un recíproco amor a la Nación, y un profundo respeto a nuestro augusto Soberano, quiero decir a CARLOS III el inmortal bienhechor de la patria, animan vuestras acciones, y en todos tiempos es vuestro principal cuidado buscar el mérito, honrarlo, y fomentar al que le tiene con vuestros auxilios y consejos» ${ }^{20}$.

17 Rodríguez de Campomanes, Pedro: «Oración Gratulatoria que dijo el Ilmo. Señor Don Pedro Rodríguez de Campomanes, del Consejo y Cámara de S. M. con motivo de la traslación de la Sociedad de Amigos del País, su abertura y colocación en la Sala que el Ilustre Ayuntamiento de Madrid la franqueó para celebración de sus Juntas; en la primera que tuvo dentro de ella el día 16 de Setiembre de 1775», Apéndice a las Memorias, Memorias de la Sociedad Económica de Madrid, t. II (en adelante, Memorias, t. II), Madrid, Imp. de don Antonio de Sancha, 1780, p. 43.

18 Rodríguez de Campomanes, Ibidem, p. 39.

19 «Este es, patriotas honrados, el loable empeño que os ha reunido en este domicilio sobre el que debéis implorar para vuestra perseverancia y concordia ante todas cosas el indefectible patrocinio del Padre de las luces». Ibidem, p. 39.

20 «El bien público es el objeto de vuestras tareas. No es el premio o alabanza pasajera lo que ha excitado la generosidad de tan honrados ciudadanos. Se sobrecargan de tareas para promover la ocupación de tanto número de personas, que carecen de ella: contribuyen con una c[u]ota anual a este fin; dedican muchas horas a consolidar la aplicación pública: deponéis todo espíritu de vanidad o presunción en vuestras conferencias, discursos y sesiones, prefiriendo siempre el mejor dictamen. No es el sofisma pueril lenguaje recibido entre los patriotas: la verdad, la modestia, la caridad con el próximo, y el conocimiento menudo de lo que se trata de decidir, es la basa de vuestros raciocinios. No perdonáis fatigas para indagar el estado de las artes, y analizar las partes más delicadas de cada ramo de industria y oficio, visitando los barrios, los talleres, los obradores, los instrumentos, y las varias maniobras de las artes con el importante empeño de conocerlas para mejorarlas a toda costa». Rodríguez De Campomanes, Ibidem, pp. 43-44. 
En estos esperanzados inicios, el ilustrado asturiano ya estaba configurando parte del vocabulario básico que caracterizó la extensa obra propagandista de la Sociedad Económica Madrileña a lo largo del último tercio del siglo XVIII; palabras como nación, patria, estado, patriota e, incluso, ciudadano, además de otras con un evidente significado político o económico, llenaron unos discursos, leídos en juntas públicas y privadas, publicados o no, dirigidos en su mayoría al propio consumo interno, pero que también saltaron los muros de la institución, con un propósito de autocomplacencia innegable y con una prosa enfervorizada, apasionada y encendida, en los que se alentaba al auditorio; arengas en las que estos hombres se definieron a sí mismos y en las que difundieron su léxico patriótico, recurriendo a conceptos en esos momentos algo imprecisos, y con el que envolvían a la monarquía con los más rutilantes adjetivos, en un esfuerzo propagandista, en el que este establecimiento se mostró especialmente dinámico ${ }^{21}$.

\section{Los Amigos del País: patriotas de la Ilustración}

La obra impresa de la Sociedad Matritense a lo largo del último tercio del siglo XVIII ofreció numerosos ejemplos del recurso a un vocabulario patriótico, que mezclaba, por una parte, la satisfacción y la ejemplaridad ${ }^{22}$, junto a otros elementos que aludían a las tradicionales lealtades identitarias. No obstante, se puede apreciar en estos discursos cierta confusión terminológica, coexistiendo voces como reino, estado, patria y nación ${ }^{23}$, con significados similares, aunque no siempre coincidentes, superpuestos, en ocasiones complementarios, no excluyentes; en general, las palabras se utilizaron con significado simbólico, que invocaba a un imaginario colectivo. Así, por ejemplo, el Estado aparece definido como «una congregación de todas las familias asociadas bajo de un propio impulso directivo» ${ }^{24}$, mientras que la política «considera al hombre en calidad de Ciudadano unido en sociedad con todos aquellos que componen el propio estado, patria, o nación ${ }^{25}$; actividad que debe estar dirigida al bien común de la colectividad, por lo que «No es menor la obligación de atender al socorro de las

21 Durante el último tercio del siglo XVIII, la Sociedad Económica Matritense celebró anualmente, al menos, una junta pública al año, donde se repartían los premios anuales a las memorias y a las mejores alumnas de las Escuelas Patrióticas. En esta ceremonia pública, a la que asistían los socios y, en ocasiones, algunos ministros, se leían estos discursos, para pasar posteriormente a la lectura de la memoria de actividades anuales, a cargo del Director. Luego, se entregaba una copia de los discursos y actividades al rey, que recibía a una comisión de socios en audiencia.

22 «Ningún personal interés, Señor, impele nuestros discursos, y experiencias. Es el bien general el que buscamos, cercenando a nuestro propio descanso el tiempo que empleamos en estas tareas», «Dedicatoria», Memorias, t. I, p. IV.

23 Varela Tortajada, op. cit. (nota 12), p. 33.

24 «Cuanto más adelante cada familia particular con su actividad, trabajo, u ocupación su bien estar, y sus haberes, tanto más robusta será la consistencia del Estado, que es una congregación de todas las familias asociadas bajo de un propio impulso directivo». «Oración Gratulatoria al nacimiento del Infante Don Carlos en el día 5 de Marzo de 1780 que presenta a S. M. la Real Sociedad Económica de Madrid de Amigos del País», Apéndice a las Memorias, Memorias de la Sociedad Económica de Madrid, t. IV, (en adelante, Memorias, t. IV), Madrid, Imp. de don Antonio de Sancha, 1787, p. 309.

25 «Sea la que fuere la forma de su gobierno [de la nación] democrático o popular, aristocrático o de nobles, o monárquico de uno solo, porque el objeto cualquiera de estos gobiernos se dirige a la utilidad común de 
necesidades públicas o promover la prosperidad común de la nación, que auxiliar y favorecer al particular, y en algún modo es preferente el amor nacional ${ }^{26}$. En este contexto, en el que los términos nación, patria y estado se emplean alternativamente, lo que se pretendía expresar es que la comunidad se articulaba en torno a un Estado monárquico, ente dotado de una concreta personalidad propia y diferencial, perfectamente definido y superpuesto a los reinos y territorios ${ }^{27}$. Así pues, la patria constituía para aquellos hombres una comunidad cultural en la que la sociedad civil debía compartir sus intereses con la sociedad política, aunque, en realidad, era la política la que trataba de vertebrar una sociedad a su medida ${ }^{28}$. Los objetivos del Estado aparecían coincidentes con los de la sociedad, o al menos, con ciertos grupos influyentes de esta, aun cuando era el propio gobierno el que estaba detrás de las iniciativas ${ }^{29}$. Por eso, no es casualidad que los tres socios fundadores de la Sociedad Económica Madrileña fueran amigos de Campomanes y procedieran de las élites del aparato administrativo estatal ${ }^{30}$. En su Exposición al Consejo de Castilla, estos fundadores manifestaban que sus ideales eran «su amor al público» y «el interés de la nación», por lo cual solicitaban la autorización para constituirse como Sociedad ${ }^{31}$. Tanto el Rey como el Consejo de Castilla, al aprobar los Estatutos, celebraron la iniciativa:

Los individuos de la Sociedad se ofrecen a beneficiar al común a propias expensas, y sin ofender a persona alguna, sacrificando sus tareas por utilidad de la Patria con este ejemplar práctico, para que en las demás provincias, a que no se extiende la Sociedad, puedan otras personas en obsequio de mis piadosas intenciones, y de las insinuaciones del Consejo, asegurando que los efectos iban correspondiendo a la bondad de la

los gobernados y a este fin fue instituido al tiempo de formar su constitución política». «Discurso preliminar», Memorias, t. I, p. XV.

26 Ibidem, p. XV.

27 En este contexto, la delimitación del término nación choca con varios obstáculos de difícil resolución, como son sus límites culturales e identitarios. En la monarquía borbónica coexistían reinos y territorios que se encontraban en continentes diferentes, cuya identidad cultural puede ponerse en cuestión, con lo cual es difícil pensar en la nación como un concepto único que significase lo mismo para todos los habitantes sometidos a la Corona. Véase Portillo VAldés, José María: «Cuerpo de nación, pueblo soberano. La representación política en la crisis de la monarquía hispana», Ayer, 61-1 (2006), pp. 47-76.

28 La comunidad cultural habría sido «impulsada desde el Estado y compuesta de individuos, ligados por sólidos vínculos de fraternidad, y amor a la patria. Regida por un rey patriota, socio o magistrado primero, enlazado a su vez o contenido por las leyes justas que han de gobernar el todo social». VARELA ToRTAJADA, op. cit. (nota 12), p. 34.

29 Para Luis Miguel Enciso se trató de resaltar la importancia de la acción política en el nacimiento de estas instituciones, en definitiva producto del utilitarismo y de la «cultura dirigida». Enciso ReCIO, Luis Miguel: «Los cauces de penetración y difusión en la península: Los viajeros y las sociedades económicas de amigos del país», en Jover Zamora, José María (dir.): Historia de España de Ramón Menéndez Pidal, t. XXXI, vol. I, Madrid, Espasa-Calpe, 1988, p. 20. Véase, además, Enciso Recio, Luis Miguel: Las Sociedades Económicas en el Siglo de las Luces, Madrid, Real Academia de la Historia, 2010, monografía que recopila algunos trabajos anteriores del autor, ampliados y actualizados.

30 Los tres socios fundadores: Vicente de Ribas, José Faustino de Medina y José de Almarza ocupaban cargos en la administración borbónica, el primero era director de la Compañía de Caracas, el segundo, secretario de la Presidencia del Consejo de Castilla y, el tercero, gobernador del Real Sitio de San Fernando.

31 «Con los objetos de mejorar, o adelantar la agricultura, la industria y los oficios, o artefactos, para lo cual se les había unido y estaban prontos a incorporarse otros vecinos». «Segunda Representación que hizo la Sociedad al Consejo, pidiendo la aprobación de sus Estatutos», Apéndice a las Memorias, Memorias, t. II, p. 10. 
empresa, tanto por el celo y buena armonía de los socios, como porque a competencia desde las clases más respetables descendía al anhelo de beneficiar al público, y ocupar la gente ociosa, anunciando tan felices principios consecuencias muy favorables, que se debían referir a las luces, que de mi orden y del Consejo se iban infundiendo en los ánimos de la Nación ${ }^{32}$.

Los «Amigos del País», en el caso de los de Madrid, cuya cercanía al foco del poder les otorgaba cierta ventaja, tenían meridianamente claro que el éxito de su empresa solo sería posible si coordinaban su trabajo con el del gobierno ${ }^{33}$. Los primeros socios fueron reclutados, en su mayor parte, entre miembros de la burocracia, estatal y local, comerciantes madrileños y otros colectivos proclives a la modernización de las estructuras económicas, pertenecientes a las élites. Este conjunto, una incipiente sociedad civil urbana que demandaba el progreso, era respetuoso con las autoridades y, a su vez, solicitaba de sus gobernantes que dirigieran sus energías, pues no bastaba con estar presto a servir a la patria, sino que era preciso que cada individuo conociera qué esfuerzos y qué acciones debía realizar:

Este amor o deseo del bien público puede convertirse en daño común si no le dirigen unos principios claros, y nada confusos, por medio de los cuales el ciudadano sepa discernir cuales son las necesidades de la patria: cuales los abusos que las originan: y cuales medios deben ponerse en obra para allegar los socorros convenientes, y que estos sean de tal bondad, que su uso aproveche al común sin perjudicar al individuo particular del estado, o al contrario ${ }^{34}$.

Estos hombres tenían clara su identidad y el espacio político que ocupaban. En los discursos se aprecia su sentido de pertenencia a un grupo más o menos homogéneo y coincidente en sus objetivos, unido por lazos fraternales; representaban a la cultura política ilustrada y racionalista, que exponía en los escritos su visión de la realidad. Un grupo que, consciente de su carácter singular y minoritario en una España todavía muy tradicional, tímidamente se abría paso hacia la modernidad y no dudaba en utilizar los medios a su disposición para difundir su ideario, recurriendo insistentemente al sentimiento patriótico, con un componente emotivo evidente que resultara atractivo a los nuevos adeptos ${ }^{35}$. En este sentido, José Vargas Ponce expresaba:

32 «Real Cedula S. M. y señores del Consejo, en que se aprueban los estatutos de la Sociedad Económica de Amigos del País, con lo demás que se expresa, a fin de promover la Agricultura, Industria, y Oficios», Apéndice a las Memorias, Memorias, t. II, p. 13.

33 «Los ingenios de la Nación aislados en sí, domiciliados en Provincias distantes, sin influjo, sin emulación y sin medios, vivían privados de sus luces, porque en tanta oscuridad no bastaban las de cada Ciudadano para iluminar la dilatada extensión de una Provincia. La Sociedad matritense colocada en el foco de esta prolongada elipse ha reunido en sí todos los rayos debilitados de estas luces segregados y como espejo de reflexión las ha rechazado más enérgicas y vigorosas, difundiendo un raudal de ilustración y conocimientos en la Nación entera», Fernández de NAvArrete, Martín: Discurso sobre los progresos que puede adquirir la economía politica con aplicación de las ciencias exactas y naturales, y con las observaciones de las Sociedades Patrióticas, Madrid, Imp. de Sancha, 1791, pp. 25-26.

34 «Discurso preliminar», Memorias, t. I, Madrid, Imp. de don Antonio de Sancha, 1780, p. XVI.

35 «La virtud cívica por excelencia, el amor a la patria, con todas las resonancias clásicas que esta expresión suscita, ya no es para estos sectores el simple enraizamiento en una tierra: implica el esfuerzo utilitario y la 
Como una la Patria, una debe ser hacia ella la obligación de todo ciudadano; pero diversificada esta al infinito en sus varias ocupaciones, solo el instituto de las Sociedades puede atraerlos por un mismo sendero a aquel centro común. El Prelado, el Pastor alistándose en ellas descubre un campo espacioso en que ejercitar su caridad, que siendo ilustrada no podrá ser dañosa. El General, el soldado, que en el sosiego de la paz se consumía sin enemigos, se alista en ellas, y con sus luces pugna contra la inacción y la ignorancia. El Magistrado que al salir del Foro hallaba horas que consagrar a la patria, se alista en ellas, y juzga y condena, las preocupaciones que empecían la actividad nacional; y si Roma nunca valió mas que cuando del arado sacaba sus Dictadores y sus Cónsules, España jamás florecerá tanto cuando sus Magistrados y sus Generales no desdeñan dedicar sus ocios a la industria y al arado. También el padre de familias, implicado en quehaceres domésticos se abochornaba de no servir a la causa pública, se alista en las Sociedades, y se transforma en un patricio padre de su pueblo y de su merindad. He aquí los establecimientos que han de cambiar la faz de la nación, pues encomendada a ellos por reducidas porciones, que conocen tanto, y en las que tienen interés tan estrecho, adecúan los abonos a sus peculiares necesidades, practican ensayos, establecen mejoras, promueven plantíos, simplifican trabajos y máquinas, los abrazan y los inventan, publicando sabias memorias, y adjudicando honrosos premios ${ }^{36}$.

Martín Fernández de Navarrete, hombre alejado de todo apasionamiento, observaba el estímulo generado por el patriotismo en los «Amigos del País»; para él, el sentimiento más destacable que compartían era el deseo de servir a los demás, el esfuerzo colectivo, la empresa digna en la que debían emplearse a fondo. El optimismo antropológico, la equilibrada racionalidad y sosegada emoción se advierten en las páginas de su discurso.

El Patriotismo parece la virtud característica de nuestros tiempos: él circula y se propaga con entusiasmo en todas las Provincias de la Nación: fecunda los talleres y los campos: sacude nuestro adormecimiento: nos prepara días serenos y apacibles; y él en fin os junta hoy en este sitio, a donde me conduce vuestra amistad a dedicarle mis votos y rendirle mis holocaustos ${ }^{37}$.

Este mensaje patriótico resultaba más emotivo, exaltado y conmovedor en el encendido verbo de Nicasio Álvarez de Cienfuegos, al señalar las metas de las sociedades económicas:

¡Qué espectáculo tan sublime presenta una asociación de personas unidas por los vínculos fraternales del patriotismo para contribuir con su talento, con su industria, con todas sus facultades a la prosperidad de la nación y a la felicidad de los particulares! Desterrar la ignorancia y la pereza asegurando la utilidad a la aplicación, a las luces, y al trabajo, tal debe ser el instituto de una Sociedad patriótica. Reformando la educación, propagando la instrucción y la industria debe procurar el bien de todos

cooperación en pro del bienestar material y la prosperidad común de España». Fernández SEBASTIÁn, op. cit. (nota 6), p. 55.

36 Vargas Ponce, José: Discurso leído a la Sociedad Matritense de los Amigos del País sobre la serie de sucesos que originaron estos establecimientos y las ventajas que proporcionan, Madrid, Imp. de Antonio Sancha, 1790, pp. 33-35.

37 Fernández de Navarrete, op. cit. (nota 33), p. 6. 
los hombres de todos estados y de todas clases, con más especialidad de aquella clase de ciudadanos cuya miseria los reduce a la más grosera estupidez y al más lastimoso abandono ${ }^{38}$.

En definitiva, era la comunidad en sentido amplio, ya fuera estado, reino, patria o nación, pero, a la vez, en sentido más reducido, pueblo, villa, ciudad o provincia ${ }^{39}$, a la que se dirigían las acciones de los miembros de estas corporaciones. Las sociedades económicas tuvieron un ámbito de actuación geográfico reducido, por lo que, un espacio mayor, es decir, diferentes territorios bajo la misma Corona, podía conciliar perfectamente con otro más limitado como era el municipio, de cara a oyentes o lectores. Esta ambigüedad terminológica también se aprecia en la utilización de un vocabulario eminentemente civil y administrativo, que no desentonaba excesivamente, pues se trataba de una sociedad que, aun siendo todavía inmovilista, estamental y heterogénea, empezaba a transformarse lentamente, identificándose como una comunidad vertebrada en torno a dos coordenadas homogeneizadoras como fueron la monarquía y el Estado, pero que no se había desprendido del componente religioso identificador, aunque este apareciera muy residualmente en este tipo de discursos:

Prosigamos pues, correspondiendo a las fundadas esperanzas del Rey, del Consejo, de nuestros Fundadores, y de la nación toda: continuemos constantes, sin que nos desanimen estorbos y contradicciones, antes bien sirvan a avivar nuestro celo; y renovemos con el año nuestros esfuerzos, para que haciéndonos útiles a la Religión, al estado, y a los pobres, merezcamos el premio que la posteridad dispensa a la virtud en el Templo de la Fama ${ }^{40}$.

\section{EI Rey: el padre de las Luces}

Si los miembros de la Sociedad Económica de Madrid podían vanagloriarse del título de «Amigos del País», no por ello dejaban de agradecer al rey, el «Padre de la Patria», que hubiera sido el primero que, con sus medidas reformistas, había señalado el camino a seguir ${ }^{41}$. El monarca encarnaba a los ojos de los miembros de la corporación, todas las virtudes públicas y privadas que se le exigían al hombre; constituía un modelo a imitar para la sociedad en general. Era el primer patriota, «un ciudadano ejemplar»,

38 Álvarez de Cienfuegos, Nicasio: Elogio del Señor D. Joseph de Almarza, Madrid, Imp. Real, 1799, pp. 36-37.

39 Fernández Sebastián, op. cit. (nota 6), p. 55.

40 Imbille, Luis de: «Elogio del Rey Nuestro Señor que en la Junta de 9 de noviembre de 1776 dijo Don Luis de Imbille, Socio de Número», Apéndice a las Memorias, Memorias, t. II, p. 50.

41 «No lo temas, gran CARLOS, nosotros seguiremos tu ejemplo, para que la posteridad agradecida a tus virtudes en medio de la posteridad que le proporcionan tus sabias y benéficas providencias, cante tus glorias, y te distinga con el dulce nombre de Padre de la Patria, que fue con el que te caractericé en el primer discurso, y con el que te conocerá en lo sucesivo toda la posteridad», GuEVARA DE VASCONCELOS, José: «Elogio al Rey Nuestro Señor que en la Junta general de 8 de Noviembre de 1777 dijo Don José de Guevara Vasconcelos, presbítero, de las Reales Academias Española, y de la Historia, Censor perpetuo de la Sociedad», Apéndice a las Memorias, Memorias, t. II, p. 55. 
digno, justo y benéfico, aunque el término ciudadano no tuviera todavía el significado, en cuestión de derechos políticos, que adquirirá en el periodo constitucional:

Una atención religiosa a no dañar a los demás, aun en las circunstancias críticas en que ninguna ley protege, descubre el carácter del hombre justo y bueno: un grande esmero en acudir a las necesidades de los otros, tomando a toda costa la parte posible en ellas, forma un ciudadano digno: un desvelo incesante por la perpetua tranquilidad y bienestar de la sociedad; el remedio posible de lo pasado, el arreglo oportuno de lo presente, y la previsión calculada de lo futuro para la observancia puntual de las leyes del orden, son los colores que más vivamente resaltan en el retrato de un Rey poseído del amor público social. El hombre justo acaso no parece un ciudadano apreciable; el ciudadano digno no siempre tiene el manejo en los negocios públicos; pero el Monarca que aspira a los elogios debidos al cumplimiento exacto de su cargo no puede menos de presentarse modelo de todos sus súbditos: solo él debe manifestar el patriotismo en toda su extensión y utilidad ${ }^{42}$.

El monarca Carlos III, fue objeto de las más entusiastas apologías, no solo por haber autorizado la creación de sociedades, sino porque en su persona se reunían todas las cualidades exigibles al buen soberano. Los Elogios anuales son variados, pero, en general, comparten la característica de exaltar sus virtudes. Frente a sus antecesores, destacaba por sus «prendas todas que sin recelo de lisonja constituyen a nuestro augusto Soberano, acreedor al título de verdadero Padre de la Patria» ${ }^{43}$. Un soberano benefactor, comprometido con el buen gobierno, preocupado por sus súbditos, partidario del progreso y del crecimiento económico, que al legislar favoreciendo el comercio, la agricultura y la industria, sentaba unas primeras y tímidas bases para la modernización de España:

En efecto, señores, cada día nos da el Rey prueba de su humanidad, de su justicia, y de su amor a la nación; pero dejando a que la historia represente a Carlos III en toda la serie de su vida, ya conquistador de Italia, ya inspirando el entusiasmo del amor, y de la fidelidad, a una Nación que antes solo conocía el delirio de la sedición, y de la anarquía, ya renovando en España el ejército, y la marina, reprimiendo con las mejores leyes los abusos, adornando su capital, y su reino, abriendo al comercio nuevas comunicaciones por mar y tierra, protegiendo las artes, reformando la educación nacional, buscando, y premiando el mérito por retirado, o descuidado que se vea, rompiendo los grillos que tenían preso y oprimido el comercio de las Colonias, y de la Metrópoli, y esparciendo, como el sol, en la vasta extensión de sus dominios la vida y la felicidad. Dejando este retrato a la Historia, me ciño únicamente a la época actual, en que hallaremos nuevos motivos de nuestra admiración, amor, y reconocimiento en las nuevas virtudes que le adornan, le ensalzan y le ilustran ${ }^{44}$.

42 A las alturas de 1800, el lenguaje ha incorporado nuevos vocablos de origen, probablemente, revolucionario, aunque todavía no se utilicen con ese propósito: de la «felicidad pública» se ha pasado al «amor público social». Ruiz de Celada, Miguel: Elogio del Rey N. S., Madrid, Imp. de Sancha, 1800, p. 2.

43 Guevara de Vasconcelos, José: «Elogio al Rey Nuestro Señor, que en la Junta de 4 de Noviembre de 1775 dijo el Señor Don José de Guevara Vasconcelos, Presbítero, Censor de la Sociedad», Apéndice a las Memorias, Memorias, t. II, p. 47.

44 GueVARa de VASCONCELOS, José: «Elogio del Rey Nuestro Señor, leído en junta general del año 1779 por Don José de Guevara Vasconcelos, Censor perpetuo de la Sociedad», Apéndice a las Memorias, Memorias, t. IV, p. 300. 
Frente a las conquistas, hazañas y toda serie de heroicidades, aparte del recurso a la virtudes religiosas, a las que generalmente se acudía a la hora de glorificar a la monarquía, para estos hombres, no tanto amigos de la acción como partidarios de la reflexión, intelectuales en su mayoría, una de las cualidades a destacar del soberano consistía en su preocupación por la mejora de las condiciones de vida de sus súbditos ${ }^{45}$. El crecimiento económico, la inversión pública, la mejora de las comunicaciones, la libertad de comercio, el favorecimiento de la agricultura, el progreso de la industria, la extensión de la educación, el interés por la ciencia, la erradicación de la pobreza, etc., es decir, todo aquello que contribuía al bienestar y la felicidad pública, era lo realmente digno de elogio.

¿A qué parte en efecto, señores, volveremos los ojos que no veamos obras inmensas, que tienen como único objeto la felicidad pública? Los caminos de Andalucía y Extremadura se están construyendo. El Jardín Botánico se levanta a nuestra vista. El Canal de Aragón se está siguiendo con vigor. La mendicidad se halla cuasi desterrada. Las Diputaciones de Barrio socorren la pobreza enferma, o débil, y ocupan la robustez perezosa ${ }^{46}$.

En definitiva, el monarca ocupaba el primer lugar en el patriotismo, y esa era la virtud que los súbditos debían apreciar y ensalzar: «Un soberano, sacando de su ignorancia y rusticidad a los sencillos labradores, promoviendo a los laboriosos artesanos y oficiales, y dispensando su protección eficaz a los individuos útiles a la nación, es un objeto muy lisonjero para todos los que están animados de un celo desinteresado por la felicidad social» ${ }^{47}$.

También Carlos IV fue objeto de la encendida oratoria de los miembros de la Sociedad Económica de Madrid: «Oíd, pues, el elogio de un Rey, formado, no a impulsos de la ambición, o de la lisonja, sino en fuerza del reconocimiento debido a las circunstancias que constituyen a CARLOS IIII. Monarca verdaderamente patriota ${ }^{48}$. Al comienzo del reinado había motivos para la esperanza:

Entra V. M a mandar cuando apenas hay cosa que no esté renovada o mejorada o nuevamente establecida. La conservación y adelantamiento de lo que está empezado hará el nombre V. M. no menos glorioso que el de su augusto padre; a lo cual parece convida esta era el grande aumento de luces y buenos deseos de toda la Nación. La Sociedad, que tantos motivos tiene para esperarlo así, no duda que V. M. con su protección la conserve en estado de poder contribuir a esta grande obra ${ }^{49}$.

En este esfuerzo propagandista hacia la Corona, que los socios sentían que era su deber realizar en correspondencia con el patrocinio con que aquella les favorecía, Mi-

45 Sobre los intelectuales y hombres de letras dieciochescos, véase ÁlvarEz BARRIENTOS, Joaquín: Los hombres de letras en la España del siglo XVIII. Apóstoles y arribistas, Madrid, Castalia, 2006.

46 Guevara de Vasconcelos, Ibidem, p. 300.

47 Ruiz De Celada, op. cit. (nota 42), p. 1.

48 Ruiz De Celada, Ibidem. pp. 1-2

49 «Oración de la Real Sociedad económica de Madrid al Rey nuestro Señor Don Carlos IV, con motivo de su exaltación al trono», Espíritu de los Mejores diarios literarios que se publican en Europa, 178 (27 de abril de 1789), p. 1142. 
guel Ruiz de Celada, en nombre de la corporación, proclamaba orgulloso: «la Sociedad Económica os ha presentado con naturalidad a CARLOS IIII, siempre apreciable por su protección eficaz, dispensada a toda clase útil al Estado ${ }^{50}$. La nación entera debía sentirse orgullosa de su rey, de igual manera que los miembros de la corporación apreciaban el favor que les dispensaba:

Dichoso Príncipe, cuyo amor público merece ser materia de los elogios de un cuerpo todo patriótico, y aun más dichosa nación, que puedes gloriarte de poseer el corazón de un Monarca, cuyas alabanzas están en sus virtudes peculiares, sin mendigar las que se dicen comunes a todos los Soberanos! ${ }^{51}$.

No obstante, estos elogios a la monarquía no se diferenciaban mucho de otros dedicados a determinados prohombres dignos de alabanza, a los que se exaltó por su contribución a la patria. Si bien es necesario insistir que en las sociedades económicas se fue configurando, a través de los discursos, un vocabulario cívico que prescindía la mayoría de las veces del elemento religioso; las virtudes del monarca o de estos españoles dignos por su patriotismo, se ensalzaban desde un punto de vista civil, laico y ético-moral. En general, las alabanzas solían separar, con especial cuidado, las virtudes cristianas del individuo en cuestión como estrictamente privadas, sin darles preferencia respecto de las virtudes públicas, que se señalaban con más detalle, pues estas eran las que debían ser objeto de emulación y de interés para el público de las sociedades económicas.

\section{Súbditos y ciudadanos}

En cierta manera, Campomanes había establecido, ya en su discurso inaugural, unas notas comunes a la obra propagandista de la Matritense en el último tercio del siglo XVIII, para definir a sus miembros. Se trataba de hombres de orden, reformistas pero no revolucionarios, ilustrados, renovadores que no se dejaban llevar por excesos, en definitiva, aquellos hombres de las élites, llamados a desempeñar altos cargos y empleos en el gobierno de la monarquía, la administración, la magistratura o el ejército, con una mentalidad abierta a las novedades que, unidos a gentes procedentes de las élites urbanas, intelectuales, científicos, artistas y al clero reformista, trabajaban por el bien común y cuyos esfuerzos individuales podían canalizarse eficazmente a través de estas corporaciones. Gentes que creían en la monarquía, que formaban parte del sistema, conscientes de que este podía ser mejorado y dispuestas a trabajar en esta dirección. Por ello, Campomanes ensalzaba sus deseos de contribuir al desarrollo económico, conceptuándoles patriotas empeñados en el progreso: «iQué dicha para el hombre ser útil a los demás de su especie! Mayor es todavía alcanzar el modo de serlo y extender incesantemente su mano bienhechora a la viuda, al huérfano, al desvalido» ${ }^{52}$.

\footnotetext{
50 Ruiz de Celada, op. cit. (nota 42), p. 24.

51 Ruiz de Celada, Ibidem, pp. 24-25.

52 Rodríguez de Campomanes, op. cit. (nota 17), p. 38.
} 
Honor y patriotismo fueron las dos características básicas que unían a los miembros de la corporación: con el primero se recompensaba su labor desinteresada, y con el segundo se hacía alusión a la condición que se les exigía al reclutarlos. Respecto al honor, tanto los Elogios fúnebres como otro tipo de textos, aprovechaban para exaltar las virtudes cívicas de los socios más destacados, cuya labor quedaba inmortalizada ${ }^{53}$. Así, en su homenaje a Ventura Rodríguez, Jovellanos, le alababa por su sabiduría: «la visteis brillar también en este santuario del patriotismo, a cuya erección concurrió, y donde le atrajeron su virtud y su celo por el bien público» ${ }^{54}$. Vargas Ponce, en su discurso de ingreso, no podía olvidar a la persona que había ideado la primera Sociedad de Amigos del País, el Conde de Peñaflorida, fundador de la Bascongada y, dejándose llevar por la emoción, exclamaba: «Si algún día dedica estatuas la España a los Héroes de un Patriotismo puro y desinteresado, te tocará la primera ilustre Peñaflorida; y en tanto lleno de gratitud, y cuanto ya no existes; a la faz de la nación, y en medio de una de las moradas que te debe la Patria, exhalo a tu memoria este suspiro de agradecimiento» ${ }^{55}$. El patriotismo, virtud cívica por excelencia, constituyó un lugar común al que acudir para inundar, desbordar e inflamar al auditorio. El discurso de ingreso de Martín Fernández de Navarrete profundizaba en este concepto:

Otras atenciones más serias y de utilidad más general ocupan vuestro tiempo y consideración: la Patria espera sus resultados; y yo que amo su bien con el ardiente interés de un verdadero Patriota, debo procurarlo igualmente desde hoy como uno de los Socios de este cuerpo. Sea pues mi silencio el primer obsequio hecho con un ánimo tan bien intencionado, hasta que vuestro ejemplo, vuestras luces y vuestras conferencias, justificando vuestra elección, me pongan en estado de llenar los deberes que inspira el Patriotismo como carácter distinguido de todo buen Amigo del País, y digno Individuo de esta sabia e ilustre Sociedad ${ }^{56}$.

En el año 1785, cuando Jovellanos ocupó el cargo de director de la Sociedad de Madrid, en su discurso de toma de posesión animaba a los socios a que se comprometieran en las tareas de la institución vinculándolo con el patriotismo, de manera que exhortaba a sus oyentes: «El público lo espera de nosotros y la gloria con que sabe recompensar a los honrados Ciudadanos que dedican a su felicidad sus útiles tareas será nuestra Corona y nuestro premio en la más remota posteridad ${ }^{57}$.

Por otra parte, la constante utilización de la voz ciudadano es una nota común a los discursos, pero no se referían a ella como sujeto titular de derechos políticos, porque la soberanía perteneciera a la nación, pues no era posible concebirla así en

53 Los Elogios fúnebres no fueron exclusivos de las Sociedades Económicas; en el caso de los escritores «eran formas, momentos y ritos que contribuían a hacerla respetable e institucional, como a sus autores, incluso si se igualaba a los mediocres con los grandes talentos, pues el objetivo de los elogios era [...] dignificar la profesión, tomando como excusa al elogiado». Álvarez BARrientos, op. cit. (nota 45), p. 190.

54 Jovellanos, Gaspar Melchor de: Elogio de D. Ventura Rodríguez, Madrid, Imp. de la viuda de Ibarra, 1788 , p. 60.

55 Vargas Ponce, op. cit. (nota 36), pp. 32-33.

56 Fernández de NavarRete, op. cit. (nota 33), pp. 37-38.

57 El discurso de toma de posesión tiene fecha de 18 de diciembre de 1784. Jovellanos, Gaspar Melchor de: «Discursos de posesión y cese de Jovellanos en la Dirección de la Real Sociedad Económica Matritense», Torre de los Lujanes, 30 (1995), pp. 127-143. 
el absolutismo y por mucho que algunos de los socios tuvieran conciencia de esta circunstancia, por más que estuvieran siguiendo con atención los sucesos ocurridos en la vecina Francia, no se hubieran atrevido a expresarlo con esa contundencia ${ }^{58}$. En realidad, se trata de un concepto algo más difuso, de un comportamiento cívico que incluye la predisposición, la utilidad, el deseo y el servicio a los demás. En este sentido se pronunciaba Vargas Ponce en 1790: «Tan convencidos fueron estos Reyes amantes de su pueblo de que no hay otro medio para hacer feliz a una Nación que ilustrarla, y que aquel será mejor ciudadano, mejor padre de familias, mejor súbdito, que más alcance y que más sepa» ${ }^{59}$.

Los socios de la Matritense se sentían satisfechos con la incipiente legislación a favor de la libertad económica, quizás esta constituyera para ellos el primer paso para adquirir una verdadera ciudadanía política; aunque todavía no era posible la igualdad de los individuos o la movilidad social, estos tímidos intentos interclasistas o, mejor, inter-estamentales, planteados ya por Campomanes, al diseñar las sociedades económicas, satisfacían a los reformadores, que se alineaban sin fisuras con las ideas del gobierno frente a los detractores de la política reformista:

Carlos III aprobando nuestros estatutos, nos ha restituido esta libertad, que jamás fue odiosa a los buenos príncipes. Sabe que esta libertad no solo es el derecho más apreciable del hombre, sino también su más noble atributo; su gran penetración le ha hecho ver que ella sola podía restituir su primitiva felicidad a la Nación, aplicando a objetos útiles y sólidos la imaginación distraída en cosas poco importantes, o acaso peligrosas. Su consumada experiencia le ha hecho conocer que era ya tiempo de sustituir las ideas de Comercio, de Artes, de Agricultura, y de Industria, a las pomposas pero funestas, de engrandecimiento, y de conquistas. Por fin nos ha recordado que éramos ciudadanos, que teníamos una patria, y debíamos contribuir a su prosperidad con nuestras luces, desvelos, $\mathrm{y}$ trabajos ${ }^{60}$.

La igualdad de sus miembros, la tímida apertura hacia una especie de experimento social, en el que nacimiento y privilegio pasaban a un segundo plano para juzgar o clasificar a los individuos, tuvo que servir de acicate y ejercer fascinación para el reclutamiento de miembros. De esta manera, en el artículo 6 de los Estatutos de la Real Sociedad, aprobados por el Consejo de Castilla en 1775, se había establecido:

\footnotetext{
58 Sobre el concepto de ciudadano en las Cortes de Cádiz y su relación el dogma de la soberanía nacional, véase VAREla SuAnZes-CARPegna, op. cit. (nota 3), pp. 194 y ss.

59 Vargas Ponce, op. cit. (nota 36), pp. 25-26.

60 Guevara de Vasconcelos, op. cit. (nota 44), pp. 300-301. Estas últimas palabras, que asocian libertad, ciudadanía y patria, aunque en un contexto muy diferente, recuerdan la famosísima frase de Argüelles: «Españoles, ya tenemos patria», en la que se refería a la reciente promulgación de la Constitución de Cádiz de 1812 , vinculando, en este caso, nación con soberanía y ciudadanos con derechos políticos. Si bien la ciudadanía se asocia a derechos políticos, respecto a las ideas económicas, los liberales recogieron la herencia de los ilustrados, así pues la «nación de propietarios» liberal no era muy distinta de la que soñaron sus antecesores más radicales de la Ilustración. No hay que olvidar que el Informe sobre la Ley Agraria de Jovellanos, surgió de la Comisión de Agricultura de la Matritense. Véase PÉREZ GARZón, Juan Sisinio: «La nación, sujeto y objeto del estado liberal español», Historia Contemporánea, 17 (1998), pp. 119-138 y LlomBART RosA, Vicent: «El "Informe de Ley Agraria" de Jovellanos: núcleo analítico, programa de reformas y fuentes intelectuales», en Fuentes Quintana, op. cit. (nota 11), p. 446.
} 
«Ningún individuo de la Sociedad gozará sueldo, o gajes, porque todos han de dedicar su celo a cumplir con los encargos que eligieren por honor, y amor de la Patria» ${ }^{61}$.

En una sociedad, todavía estamental, en la que el nacimiento era la causa del puesto que el individuo ocupaba en la sociedad, en la que la pertenencia a un grupo privilegiado constituía un aspecto importante del rol que el individuo representaba en la colectividad y formaba parte de su ser mismo como persona y como parte del grupo, pues sólo así era considerado por sus semejantes, se fue abriendo progresivamente la puerta al papel del esfuerzo, el mérito y el éxito, a lo que estas instituciones contribuyeron con acierto ${ }^{62}$. El hecho de que todos los miembros de las sociedades económicas fueran iguales, abría las puertas a unos iniciales y tímidos signos de permeabilidad social ${ }^{63}$. La creación de la figura de los socios de mérito, reservada a aquellos que sobresalieran en alguna actividad económica o intelectual, debía resultar atractiva, por lo novedoso, a los que no pertenecían a los grupos privilegiados ${ }^{64}$. Ya en los Estatutos de la institución se diferenciaba claramente a aquellos socios que contribuían con su cuota, de la que no estaban exentos ni la nobleza ni el clero, de los que, como socios de mérito, por su destacada aportación en alguna actividad científica, intelectual o económica, estaban exentos de pago. La contribución a las luces, y el amor a la patria, consustancial a esa aportación, puesto que todos trabajaban por el bien común, eran circunstancias que, a la vez que privilegiaban a ciertos miembros, igualaban a todos ${ }^{65}$ :

Sí: Señores, gracias a nuestros Fundadores, ya está despierto el amor patriótico, porque ¿qué otro impulso sino el suyo, unido con el espíritu de una entendida caridad, conduce tan puntualmente a nuestras juntas al Grande, al General, al Magistrado, al Eclesiástico y a todos nuestros dignísimos Individuos? [...] ¿y qué otro impulso, vuelvo a decir, puede animar a cada uno de nuestros Ilustres Socios, a desempeñar con tanta puntualidad y acierto, a expensas de los mayores desvelos, los encargos, y comisiones que se les encomiendan? Estos prodigios solos los produce el amor a la Patria, sostenido de una solida caridad ${ }^{66}$.

61 «Estatutos para la Sociedad Económica de Madrid de los Amigos del País», Apéndice a las Memorias, Memorias, t. II, p. 14.

62 «En el titulo III se arregla el orden de las juntas o concurrencias de los Socios: todos se sientan según van entrando: toda preferencia es desconocida, salvo la del mayor celo y talento en los objetos a que se dedica la Sociedad: las disputas o alteraciones no tienen lugar en las juntas, ni las repeticiones molestas o fastidiosas». «Discurso preliminar», Memorias, t. I, p. XX.

63 «En el I y II título establece el número indeterminado de individuos: destierra toda preferencia, salvo la del Director que debe presidir: distingue Socios de número, y correspondientes, cuya distinción solo consiste en el lugar de la residencia, por que viniendo a Madrid gozan de una perfecta igualdad». Ibidem, p. XX.

64 «La misma les atribuye a los Socios de mérito, con la sola diferencia de estar en su arbitrio contribuir o no con la cuota anual señalada de dos doblones». Ibidem, p. XX.

65 «Tales Sociedades en donde el Grande al lado del artista, la toga junto a la espada, solo atienden con un tráfico recíproco de luces a mantener en fermentación su patriotismo, son las que aumentando los Escritos Geopónicos, descubriendo manantiales a la industria, y fructuosas sendas al comercio, ponen en un estado floreciente a la Patria». Vargas Ponce, op. cit. (nota 36), p. 36.

66 ImBILle, op. cit. (nota 40), pp. 49-50. 
En palabras de Jovellanos, si algún suceso habría de ser recordado del reinado de Carlos III, sin duda era la creación de las sociedades económicas, precisamente por conciliar los intereses de los diferentes estamentos,

Estos cuerpos llaman hacia sus operaciones la expectación general, y todos corren a alistarse en ellos. El clero, atraído por la analogía de su objeto con el de su ministerio benéfico y piadoso; la magistratura, despojada por algunos instantes del aparato de su autoridad; la nobleza, olvidada de sus prerrogativas; los literatos, los negociantes, los artistas, desnudos de las aficiones de su interés personal, y tocados del deseo del bien común, todos se reúnen, se reconocen ciudadanos, se confiesan miembros de la asociación general antes que de su clase, y se preparan a trabajar por la utilidad de sus hermanos. El celo y la sabiduría juntan sus fuerzas, el patriotismo hierve, y la nación atónita, ve por primera vez vueltos hacia sí los corazones de sus hijos ${ }^{67}$.

Estos hombres «honrados ciudadanos» a los que se refería Jovellanos insistentemente en sus discursos, para estimular a su auditorio, aunaban ciertas características, que fueron destacadas en los elogios fúnebres, textos en los que la sociedad fue muy prolífica, pues Campomanes creía que la emulación, junto a la educación, era una de las mejores formas de impulsar el progreso ${ }^{68}$. Dependiendo del orador, el discurso podía tener mayor o menor calidad literaria; en el caso de Álvarez de Cienfuegos, con su elocuencia y lirismo consiguió emocionar a sus oyentes en su Elogio del Señor D. Joseph de Almarza, uno de los socios fundadores de la corporación madrileña ${ }^{69}$ :

¡Oh Almarza, Almarza! ¡Oh templo ya arruinado de la beneficencia! Descansa tranquilamente en el silencio de tu sepulcro, y goza de los premios sempiternos debidos a tus virtudes. Y si la voz de los mortales penetra hasta el reino de la muerte, dígnate recibir nuestras lágrimas como un tributo de nuestra admiración, de nuestro agradecimiento, y de nuestros pesares. En ellos vivirás largamente, y la memoria de tus buenos ejemplos, que procuraremos imitar a porfía, será un monumento más duradero que los magníficos mausoleos que la vanidad de los hombres levanta para eternizar su nada. El tiempo pasa, derriba los mausoleos, huella los obeliscos, borra las inscripciones, y la noche del olvido se tiende sobre la grandiosidad de sus ruinas. ¿Qué es lo que se salva de este universal trastorno? El nombre de algún virtuoso que, grabado en los corazones de sus semejantes reconocidos, pasó de lengua en lengua, y vive en los ca-

67 Jovellanos, Gaspar Melchor de: Elogio de Carlos Tercero, Madrid, Imp. de la viuda de Ibarra, 1789 , pp. 44-45.

68 «Ordenan los estatutos que por punto general se hagan elogios fúnebres a los Individuos luego que fallezcan, siendo conveniente conservar la memoria de los honrados ciudadanos que con tanto ahínco se emplean en el bien de su patria: pues nada es tan conducente a inflamar los ánimos y estimularles al ejercicio de sus funciones, como el digno aprecio de los que llenaron, y también para formar el gusto general en una materia poco cultivada entre nosotros». «Advertencia», Apéndice a las Memorias, Memorias, t. II, s/p.

69 «Sí; aquí mismo, en este templo de la patria que nos congrega, bajo este techo que nos abriga, en este día que nos alumbra, y tal vez en este mismo asiento en que mi lengua suspende el silencio de su sepulcro; aquí mismo le visteis mil veces apadrinando la agricultura, protegiendo las artes, vivificando la industria, y triunfando de la ociosidad contagiosa por medio de la educación de la niñez, tan largo tiempo abandonada. ¡Felices una y mil veces vosotros! que, si sentís el dolor de haberle perdido, tenéis a lo menos el consuelo de haber gozado de su presencia, de haber oído hablar por su boca al patriotismo, de haber sido testigos de una vida pura y hermosa, y objeto del cariño de un corazón todo amor y beneficencia». ÁllvAREZ DE CIENFUEGOS, op. cit. (nota 38), pp. 6-8. 
racteres indelebles del historiador de su vida. ¡Oh Almarza, Almarza! Tú vivirás en los de este elogio si mi elocuencia igualase a mi voluntad y a tus merecimientos. Pero ellos solos llamarán la atención de la posteridad cuando, cansada ya de admirar esos hombres grandes que son grandes calamidades para la tierra, vuelva los ojos hacia el espectáculo pacífico de las virtudes domésticas y civiles, y de esta beneficencia que reúne a los hombres con los vínculos hermosos de la fraternidad. Entonces la relación de tus ejemplos enternecerá las almas, las moverá dulcemente a la imitación de ellos, y Almarza desde su tumba continuará ejercitando su oficiosidad y su amor al género humano ${ }^{70}$.

Cabarrús, sin embargo, menos dado a la evocación de imágenes literarias, destacaba los aciertos en el ministerio de Miguel Múzquiz, conde de Gausa:

Así, pues, recorriendo todas las relaciones de la industria se descubre estampado en ellas el celo y el patriotismo de D. Miguel de Múzquiz. Hay ramos enteramente creados por él: los hay restaurados y perfeccionados; y acaso no existe uno que no le haya debido fomento y protección. Enseñanza, máquinas, exenciones, premios, honores, nada dificulta, nada escasea. El comerciante, el fabricante, el artista, el simple artesano, tienen facilidad de hablarle a todas horas; y si no hallan siempre todos los auxilios que pretenden, vuelven a lo menos contentos de aquella acogida lisonjera, que cuesta tan poco a la autoridad, y es el agente más seguro de que puede servirse ${ }^{71}$.

Sin duda, el perfil de aquellos que se acercaron a la Sociedad Económica de Madrid y, por extrapolación, al resto de sociedades, fue el de un hombre respetuoso, consciente y comprometido, que anhelaba trabajar por sus semejantes. En el Elogio fúnebre a la memoria de Francisco de la Torre, su autor Joaquín de Romaña, señalaba la triple vertiente del individuo homenajeado: cristiano, súbdito y ciudadano. Tres niveles independientes, complementarios y no excluyentes, que adornaban a la persona recién fallecida:

En fin, establecido y avecindado en esta Capital en calidad de hijodalgo, y encargado de sostener su familia con distinción y edificación, se mostró siempre el padre más tierno de toda ella, haciendo el uso debido de las riquezas que la fortuna le daba a manos llenas, sin perder de vista jamás el primer objeto de Cristianismo en que fue sólido, sirviendo a la religión con su ejemplo, y obras de caridad perfecta, y llenando con su celo todas las obligaciones de un verdadero católico.

Fue súbdito fiel, y como tal, no solo amó y respetó a su Rey, sino también a sus Ministros y magistrados que en todos tiempos le dieron pruebas autenticas de su benevolencia y estimación.

Como buen ciudadano amó el estado y la patria, en cuyo beneficio era su anhelo infatigable, y no perdía ocasión de este género en que pudiese ejercitar esta virtud natural y tan propia del hombre civilizado, llenando al mismo tiempo con dedicación y liberalidad las funciones de Socio de número de esta nuestra Real Sociedad, a que

70 Álvarez de Cienfuegos, Ibidem, pp. 53-55.

71 Cabarrús, Francisco de: Elogio del Excelentísimo Señor Conde de Gausa, Madrid, Imp. de la viuda de Ibarra, 1786, pp. 37-38. 
le condujo tan radicada inclinación y el ardiente deseo de que para obrar bien se hallaba siempre inflamado ${ }^{72}$.

\section{Legitimación, decadencia y oposición}

No obstante, los ilustrados conscientes de que esta nueva idea de patriotismo civil, en el que el componente cristiano pasaba a un segundo plano o desaparecía casi totalmente, podía despertar suspicacias en sectores más conservadores, ya que se alejaba del tradicional discurso religioso de la legitimidad divina, de miembros de una comunidad unida por un vínculo cristiano, en el que la ayuda al prójimo constituía un deber de todo católico, encontraron en el discurso historicista, tan en boga en aquella época, un origen al que aferrarse en su interés por los problemas de la nación. Para Jovellanos, el antecedente de este celoso patriotismo civil, que iban a encarnar las sociedades económicas, se hallaba en aquellos que sentaron las bases de la regeneración a través de formulaciones teóricas: los arbitristas, hombres observadores y preocupados por la decadencia de su patria que, a finales del siglo XVII, habían empezado a denunciar los males que sufría España. El estudio de la economía política era un punto de partida para reconocer el atraso y empezar a buscar una solución. Así pues, el patriotismo no solo consistía en un deseo de ser útil por parte de cada individuo, sino que para poder ejercerlo dignamente, era indispensable contribuir con las «luces», en el sentido de aprender con el estudio de la economía política:

Entonces fue cuando el espectro de la miseria, volando sobre los campos incultos, sobre los talleres desiertos y sobre los pueblos desamparados, difundió por todas partes el horror y la lástima; entonces fue cuando el patriotismo inflamó el celo de algunos generosos españoles, que tanto meditaron sobre los males públicos y tan vigorosamente clamaron por su reforma; entonces cuando se pensó por primera vez que había una ciencia que enseñaba a gobernar los hombres y hacerlos felices; entonces, finalmente, cuando del seno mismo de la ignorancia y el desorden nació el estudio de la economía civil $^{73}$.

Constante común, que se repite en otros escritos de la Sociedad, en los que el interés por la economía se conjuga con el patriotismo ${ }^{74}$. El éxito inicial con el que se animó por toda España la empresa de constituir sociedades fue debidamente ensal-

72 Romaña, Joaquín de: «Elogio Fúnebre a la memoria de don Francisco de la Torre, leído por el Señor Don Joaquín de Romaña, Socio de número, [1779]», Apéndice a las Memorias, Memorias, t. IV, p. 317.

73 Jovellanos, op. cit. (nota 67), pp. 16-17.

74 «Considera el patriota instruido en los principios económicos, las ocupaciones de los habitantes: cuales viven ociosos, y el modo de emplearlos: analiza los diferentes ramos de la agricultura: la industria que corresponde a las diversas edades, sexos, y clases, proporcionando a todas empleo útil porque nadie deje de serlo en el Estado: recorre los oficios, examina su legislación gremial, los vicios que se oponen al progreso de las artes, el modo con que se ejercitan, y los medios de ponerlas en la debida estimación, sacándolas del abatimiento reprehensible para estimular sus progresos». «Oración Gratulatoria al nacimiento del Infante Don Carlos en el día 5 de Marzo de 1780 que presenta a S. M. la Real Sociedad Económica de Madrid de Amigos del País», Apéndice a las Memorias, Memorias, t. IV, p. 309. 
zado, por algunos de sus miembros; así en el Elogio anual al Rey de 1779, el censor de la Sociedad madrileña, José de Guevara Vasconcelos, hacía recuento de los éxitos:

Las Sociedades Patrióticas se multiplican, y con ellas la enseñanza, la aplicación, y la industria. Digan lo que quieran la detracción, y la envidia, estos cuerpos son los que pueden producir al estado la felicidad pública, aunque carezcan en el día de la perfección a que pueden, y deben aspirar. ¿Ni cómo sería posible, que acabando de salir entre las ruinas de una legislación, que por espacio de dos siglos parece que se complacía, no solo en descuidar los importantes objetos del instituto de las Sociedades, sino en amontonar errores acerca de ellos, se levante repentinamente un edificio sólido, regular, y aun perfecto? Contentémonos con haber puesto los cimientos de esta obra, tal vez más difícil, antes de estos establecimientos, de los que se piensa, porque aislados unos vasallos, o empleados otros en la administración, se dividían entre detractores, o aduladores, y se miraba como una especie de sacrilegio estudiar los intereses políticos de la Nación, buscar en las leyes la causa de la decadencia, y proponer los medios de reforzarla ${ }^{75}$.

Cabarrús también expresó claramente el papel que debían desarrollar las sociedades económicas. En su Elogio de Carlos III ya había expuesto sucintamente cuales eran las causas que impedían el progreso del país:

Empecemos por convenir en estos principios importantes: fijémonos en un corto número de verdades elementales: repitamos continuamente que un país adquiere siempre toda la industria que es capaz de tener, como no haya obstáculos que contrarresten su energía espontánea: que estos obstáculos vienen de la naturaleza, de la legislación o de la opinión: que los de la naturaleza se dirimen con abrir comunicaciones: los de la legislación con destruir prohibiciones absurdas, derechos excesivos, o ilusorios, trabas o arbitrios exterminadores; y que sin más acción ni dispendio por parte del Gobierno, brotará la industria por sí misma, siempre que circulen libremente las luces que han de triunfar sobre los obstáculos de opinión ${ }^{76}$.

Retomando el mismo esquema, en sus Cartas sobre los obstáculos que la naturaleza, la opinión y las leyes imponen a la felicidad pública, escritas en 1792, elaboraba todo un programa en el que estas instituciones, mediante una labor de difusión, se convertirían en uno de los medios para «hacer refluir [...] los progresos de la Ilustración ${ }^{77}$. Decididamente partidario de estas agrupaciones consideraba que «Estos establecimientos admirables en su objeto han permanecido en una infancia, de que sería ya largo sacarlos» ${ }^{78}$. Para ello no sólo tenían que encargarse de la pro-

75 Guevara de Vasconcelos, op. cit. (nota 44), pp. 300-301.

76 Cabarrús, Francisco de: Elogio de Carlos III, Madrid, Imp. de Antonio Sancha, 1789, p. XXX. Esta misma idea, ya la había expresado años antes en el Elogio del Excelentísimo Señor Conde de Gausa: «persuadido de la influencia que tienen las luces en la prosperidad de los Estados, creía que ellas solas derramadas por todas las Provincias podrían triunfar un día de los obstáculos que impiden su progreso; y que las Sociedades económicas, a pesar de los defectos de su gobierno, iban a preparar en silencio esta revolución, que ha de restituir a la España su antigua superioridad». CABARRÚs, op. cit. (nota 71), p. 40.

77 CABARrús, Francisco de: Cartas sobre los obstáculos que la naturaleza, la opinión y las leyes imponen a la felicidad pública, Madrid, Fundación Banco Exterior, 1990, p. 91.

78 CABARrús, Ibidem, p. 91. 
moción y difusión de las ideas económicas, sino que además Cabarrús les asignaba un verdadero programa que promoviese el crecimiento económico, la instrucción de la población y la concienciación política, mediante la confección de catecismos políticos que recogiesen «La constitución del estado, los derechos y obligaciones del ciudadano, la definición de las leyes, la utilidad de su observancia, los prejuicios de su quebrantamiento» ${ }^{79}$. De esta manera los obstáculos de la opinión podrían ser combatidos «y sólo cederán a la libertad de comunicación de ideas, a una educación elemental, simple y preservativa de errores, que toda una generación debe recibir; y que $[\ldots]$ preste auxilio a las que inmediatamente proceden la felicidad y prosperidad común» ${ }^{80}$.

Para Cabarrús, muchos de los hombres que componían las sociedades económicas reunían las condiciones y características necesarias para implicarse, puesto que «la idea de contribuir de un modo tan eficaz a la felicidad nacional sería la más dulce recompensa» ${ }^{81}$. En este sentido, el progreso dependía directamente de la adquisición y extensión de un determinado nivel de desarrollo social, ya que «Las artes y las ciencias no necesitan más fomento que la libertad, el interés particular, la opinión pública, y las luces que brotan en cualquier sociedad política que no las contradiga» ${ }^{82}$.

Sin embargo, los discursos patrióticos no fueron suficientes para excitar el celo de los individuos, pues ya en 1780, el censor José de Guevara Vasconcelos se quejaba de que el entusiasmo inicial había derivado a un desinterés general, preludio de la decadencia:

Pero cuando yo considero por una parte las providencias y benignas disposiciones del Rey para cuanto es útil a sus pueblos, y por otra parte noto la tibieza con que los mismos que se han ofrecido a servir a su patria, miran los asuntos que más directamente pueden influir en la felicidad común. Cuando veo casi desierto este santuario del patriotismo, no me queda otro arbitrio que exclamar con Cicerón, ¡oh tiempos! ¡oh costumbres! ${ }^{83}$.

A pesar de los esfuerzos, la Sociedad no estaba teniendo todo el éxito que se había pronosticado en sus inicios, pero seguía, perseverante, alentando a su auditorio:

Renuévese, señores, con el año el fervor con que principiamos a dedicarnos al beneficio público. Demos al Rey esta prueba de que sabemos agradecer sus beneficios. Ella será la más digna acción de gracias que podemos llevar a los pies del Trono. Demos esta prueba a la patria, y démosla a nosotros mismos ${ }^{84}$.

${ }^{79}$ CABARRÚs, Ibidem, p. 80.

${ }^{80}$ CABARRús, Ibidem, p. 92.

${ }^{81}$ CABARRús, Ibidem, p. 80.

82 CABarrús, Ibidem, p. 118.

83 Guevara de Vasconcelos, José: «Elogio del Rey, leído en la junta general de 4 de Noviembre de 1780, por Don José de Guevara Vasconcelos, Censor perpetuo de la Sociedad», Apéndice a las Memorias, Memorias, t. IV, p. 306.

84 Guevara de Vasconcelos, Ibidem, p. 306. 
Las primeras muestras de desaliento estaban muy próximas a aparecer. La continua oposición de sectores reaccionarios, unido al lento progreso de los trabajos, afectaban incluso a los socios más implicados.

Sin el apoyo de V. M. y su constante amor al bien de los hombres no faltarían personas débiles, que ignorando la excelencia, y la necesidad de nuestras tareas, desalentasen las primeras tentativas y esfuerzos que tienen el noble objeto de la enseñanza y la aplicación de la ciencia económica: ciencia que tomando sus primeros elementos del gobierno doméstico, o paterno de una familia o casa, explaya y extiende sus ideas a todo el cuerpo del Estado ${ }^{85}$.

El origen del problema de la decadencia no solo estaba en el desaliento y la inconstancia, también fue debido una política masiva de puertas abiertas, que produjo la proliferación de arribistas y ambiciosos, que solo buscaban en el título de socio un diploma más que adjuntar a las «relaciones de méritos» ${ }^{86}$.

Si ya en 1780 se observaban las primeras muestras de agotamiento, en 1786 el panorama era desolador, con algunas excepciones. Los informes enviados al Consejo de Castilla, con motivo del expediente abierto a consecuencia de la decadencia de sociedades, fueron de todas clases; mientras en unos se reconocía el declive, otros, en cambio, se manifestaban en desacuerdo. La Sociedad de Madrid fue una de las que contestó, negando la mayor, en parte debido a la atracción que ejercía su cercanía a la Corte y a la protección dispensada por el gobierno. No obstante, esta era la consigna de cara al exterior, ya que de puertas para dentro las cosas no estaban tan claras. Problemas de personalismos, disidencias y choque de voluntades entre los partidarios de políticas más aperturistas y otros más moderados, habían hecho mella en una institución, en la que el equilibrio entre ideas de unos y otros no resultaba fácil ${ }^{87}$. Los inmensos obstáculos (desunión, un ambiente poco propicio, descoordinación, desencanto, falta de fondos, trabas gubernativas y administrativas, etc.) a los que debían hacer frente desalentaban, incluso, al más ardiente, celoso y optimista socio.

Precisamente, la pertenencia al grupo, el de los «Amigos de País», y seguramente las actitudes exageradas de patriotismo de las que hacían gala algunos de los miembros, cuyas motivaciones ocultaban intereses no del todo legítimos, fueron motivo de ridiculización y sátira por aquellos que percibieron en estas maneras indicios de

85 «Oración Gratulatoria al nacimiento del Infante Don Carlos en el día 5 de Marzo de 1780 que presenta a S. M. la Real Sociedad Económica de Madrid de Amigos del País», Apéndice a las Memorias, Memorias, t. IV, p. 309.

86 En 1802, la Matritense aprobó un nuevo reglamento de socios que endurecía las condiciones de acceso. Al mismo tiempo, procedió a borrar del catálogo a aquellos que no estuvieran al corriente de las cuotas y estableció un nuevo procedimiento de elección de los cargos directivos, en el que se exigía una asistencia mínima a las juntas y comisiones para poder ejercer el derecho al voto.

87 De hecho, los socios eran conscientes de que existían algunas divergencias entre ellos: «Tal vez, concede, se hayan notado [...] algunos partidos destructivos de la buena armonía que debe reinar. Pero este mal, lo juzgo inevitable a todos. Lo empieza la diversidad de opinión, lo acalora la dificultad de convencerse y la decisión, que necesariamente desagrada a algunos, lo perpetúa. La docilidad debiera caracterizar a todos. Pero la reunión de un número crecido de entendimientos dóciles que no degeneren en serviles, me parecería un fenómeno». «Dictamen del Sr. Azcargorta, Madrid, 31 de agosto de 1786». Citado por DemERSON, Paula y Jorge: «La decadencia de las Reales Sociedades Económicas de Amigos del País», Anejos del BOCES.XVIII, 1 (1978), p. 41. 
alejamiento de los valores tradicionales que constituían el esencia de la comunidad, configurados en torno a la monarquía y la religión. Si su respeto a la monarquía no podía ser criticado, ya que no dieron muestras de deslealtad a la Corona, no ocurría lo mismo respecto a la religión. El interés por las lecturas de libros prohibidos, para los que ciertos miembros de las sociedades tenían licencia, así como el hecho de que pudieran darse casos en los que sus acciones no estuvieran de acuerdo con el mensaje que predicaban, los hacía vulnerables a la crítica. La oposición, procedente de sectores inmovilistas y reaccionarios, denunciada por los propios miembros de las sociedades económicas, utilizó todos los medios a su alcance para desprestigiarlos. Sirva como ejemplo los siguientes versos dirigidos contra Lorenzo Normante y Carcavilla, profesor de la primera cátedra de Economía política que se instauró en España, en la Sociedad Económica Aragonesa, que fue perseguido por la Inquisición.
A Santo Tomás no lee, ni a San Agustín divino, ni a las Santas Escrituras, ni a los Sagrados Concilios.
Tiene sobre su bufete y repasa de continuo al señor de Montesquieu, al Genovesi ladino y todo autor extranjero, y de tronco francesino, aunque por la Inquisición haya sido perseguido.
Los que se llaman señores y aparecen ser más ricos, más amantes de la Patria, y del País más Amigos lo que deben no lo pagan al artesano sencillo, y a este si tiene una deuda, me lo llevan al presidio ${ }^{88}$.

\section{A modo de conclusión}

En el presente trabajo se ha intentado dar una aproximación al ideario patriótico de la Sociedad Económica Matritense de Amigos del País. Sin embargo, no podríamos terminar sin hablar, siquiera brevemente, acerca de si la percepción que los «Amigos del País madrileños» tenían de sí mismos, fue extrapolable al resto de sociedades económicas, a esos «Cuerpos Patrióticos», como a veces se denominaron; si ese patriotismo que pregonaron los socios con tanta insistencia fue nota común. La respuesta es afirmativa. Todos sus miembros sintieron que pertenecían al exclusivo grupo de los

88 Forniés CAsals, José Francisco: «Las tribulaciones económicas de Lorenzo Normante y Carcavilla», en Fuentes Quintana, op. cit. (nota 11), pp. 611-612. 
«amantes de la patria», ya estuvieran en la Valenciana, en la Aragonesa, en la Sevillana, en Alaejos (Valladolid), La Laguna, Sanlúcar de Barrameda, La Habana, Quito, Lima o, territorios mucho más recónditos como Santa Cruz de Mompox (Virreinato de Nueva Granada) o las islas Filipinas, por citar algunos ejemplos de sociedades que, aunque con trayectorias distintas, algunas con gran actividad y otras breves o intermitentes, fueron creadas en el siglo XVIII ${ }^{89}$. La Matritense (a cuyo análisis se ha limitado este trabajo) es solo una muestra de un proceso que se observa también en las demás sociedades económicas repartidas por los dominios de la monarquía hispánica, desde las más prolíficas hasta las más humildes. La abundancia de textos escritos, publicados o no, ya fueran discursos, oraciones gratulatorias o elogios fúnebres, elaborados por estas instituciones, constituyen un testimonio claro de un proceso propagandista en el que los socios de todas las sociedades económicas se implicaron con convicción.

Todas ellas, con sus matices y sus ambigüedades, sus logros y sus fracasos, se fundaron con objetivos muy similares, para contribuir a la mejora de las condiciones económicas y materiales en su entorno de influencia. Todas trabajaron por la patria y así lo proclamaron en sus Estatutos, en sus emblemas y en su obra impresa. Aquí surge la cuestión: ¿qué entendían por patria? ¿Era la misma patria la que proclamaba el socio de Manila que el de Zaragoza? Si nos ceñimos al ámbito de influencia geográfico, tajantemente no, pero si lo consideramos como el deber de participar en el progreso, de auxiliar a la monarquía, allí donde no llegaban sus medidas reformistas, todos ellos seguramente entendían prácticamente lo mismo, con muy leves matices. Todos ellos concibieron al rey, al frente de la estructura del Estado, como una realidad identitaria común. La nación, con todas las ambigüedades que este término conllevaba, no era entendible, más que como una parte intrínseca de la monarquía ${ }^{90}$. El amor a la patria se juzgó como el deber de aportar sus esfuerzos por el bien de la comunidad, tanto en sentido estricto, la más cercana, como en sentido amplio, toda la colectividad, unida bajo la misma Corona. Solo la monarquía y el Estado tenían una personalidad propia, identificable y definida, que congregaba las lealtades. Todos ellos se consideraron así mismos «honrados patriotas», unidos por una identidad de intereses que trascendía lo local, su ámbito natural de actuación, para convertirse en algo más extenso. Así pues, proclamaron orgullosos su pertenencia a una minoría, la de los reformistas coordinados que habían acudido al llamamiento de Campomanes, que se sentían unidos por unos lazos afectivos y un imaginario simbólico. Quizás pudo existir una conciencia pre-nacional imprecisa, pero esta no pudo adquirir una

89 Véase Anes Álvarez de Castrillón, op. cit. (nota 13); Demerson, Paula y Jorge y Aguilar Piñal, Francisco: Las Sociedades Económicas en el siglo XVIII. Guía del Investigador, San Sebastián, CSIC, 1974; Enciso Recio, Luis Miguel: op. cit. (nota 29); Navarro Azcue, Concepción: «Las Reales Sociedades Económicas en América», Torre de los Lujanes, 67 (2010), pp. 39-61; y SHAFER, Robert Jones: The Economic Societies in the Spanish World (1763-1821), Syracuse, Syracuse University Press, 1958.

90 La definición de nación de los constituyentes gaditanos, sin embargo, es entendida como poder constituyente en el que reside la soberanía y «que pone término pues a la hasta entonces legitimidad históricadivina monárquica tradicional del poder político y de la promulgación de sus consecuentes reglas de ordenación política». GonzÁlez-Trevijano SÁncheZ, Pedro: «El concepto de nación en la Constitución de Cádiz», en Escudero López, José Antonio (dir.): Cortes y Constitución de Cádiz. 200 años, t. II, Madrid, Fundación Rafael del Pino y Espasa Libros, 2011, p. 616. 
legitimación de cara a la mayoría, ni conectar con ella, al no ser catalizadores de un mensaje que se extendiera y fuera atractivo para las masas. Su escasa difusión fuera de estos círculos reformistas y elitistas, lo redujo al autoconsumo. Por otra parte, estos grupos no entraron en conflicto con el Estado o la monarquía, sino que se valieron de las instituciones, apoyando las políticas reformistas, para poder alcanzar algunas de sus reivindicaciones.

Así mismo, este grupo estaba unido por intereses comunes, porque el desarrollo, a la vez suponía su propia mejora, ya fuera eliminando obstáculos económicos o intelectuales. Las escasas minorías avanzadas, adheridas al impulso renovador se pusieron decididamente al servicio del programa reformista oficial a través de las sociedades económicas. Unas élites, conocedoras y atentas a las corrientes económicas europeas e influidas por el espíritu enciclopedista que encontraron así la manera de poder sustraerse a los controles de pensamiento; ya procedieran de la Administración, la nobleza, el clero ilustrado, del comercio, profesiones liberales, la ciencia, las artes o literatura, compartían una misma mentalidad. Las sociedades constituyeron un punto de encuentro de los interesados en las materias económicas, a la vez que desarrollaron un gran papel en el campo de la libertad de ideas que algunas proclamaron de una manera evidente ${ }^{91}$. Un grupo que necesitó dotarse de una justificación contra un enemigo común, el inmovilismo; que encontró en la monarquía un aliado para lograr sus aspiraciones. Sin embargo, a principios del siglo XIX, esta similitud de intereses con la Corona empezó a resquebrajarse por el desprestigio y desgaste que sufrió por Carlos IV durante su reinado. Los impulsos reformistas no habían avanzado al ritmo que algunos espíritus más radicales demandaban ${ }^{92}$.

\footnotetext{
91 Llombart Rosa y Astigarraga Goenaga, op. cit. (nota 11), pp. 678 y 703.

92 Véase Álvarez Barrientos, Joaquín (ed.): Se hicieron literatos para ser políticos. Cultura y política en la España de Carlos IV y Fernando VII, Cádiz, Biblioteca Nueva, 2004.
} 